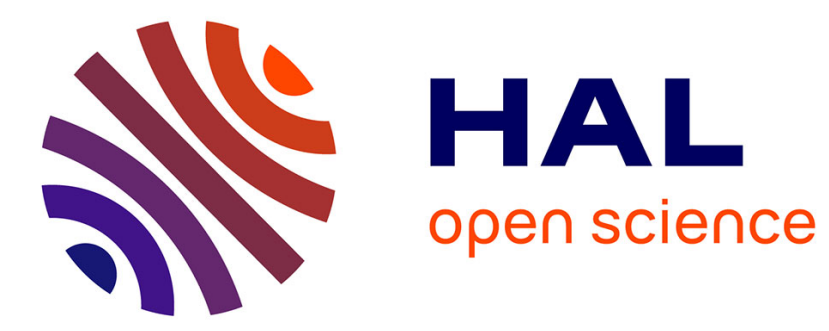

\title{
Function of the serotonin 5-hydroxytryptamine 2B receptor in pulmonary hypertension
}

L Launay, P. Herve, K. Peoc'H, C. Tournois, C Callebert, Canan G Nebigil, N. Etienne, L. Drouet, M. Humbert, G. Simonneau, et al.

\section{- To cite this version:}

L Launay, P. Herve, K. Peoc'H, C. Tournois, C Callebert, et al.. Function of the serotonin 5hydroxytryptamine 2B receptor in pulmonary hypertension. Nature Medicine, 2002, 8 (10), pp.11291135. 10.1038/nm764. hal-01985063

\section{HAL Id: hal-01985063 https://hal.science/hal-01985063}

Submitted on 25 Jan 2019

HAL is a multi-disciplinary open access archive for the deposit and dissemination of scientific research documents, whether they are published or not. The documents may come from teaching and research institutions in France or abroad, or from public or private research centers.
L'archive ouverte pluridisciplinaire HAL, est destinée au dépôt et à la diffusion de documents scientifiques de niveau recherche, publiés ou non, émanant des établissements d'enseignement et de recherche français ou étrangers, des laboratoires publics ou privés. 
Function of the serotonin 5-hydroxytryptamine 2B receptor in pulmonary hypertension.

J.-M. Launay*, P. Hervé†, K. Peoc'h*, C. Tournois*, J. Callebert*, C.G. Nebigilł, N. Etienneł, L. Drouet*, M. Humbert§, G. Simonneau§, and L. Maroteaux $\$$.

*CR C. Bernard "Pathologie expérimentale et communications cellulaires", IFR6, Services de Biochimie et d'Angio-Hématologie, Hôpital Lariboisière AP-HP, Paris France. FCentre Chirurgical Marie Lannelongue, Le Plessis-Robinson - France. $\S P n e u m o n o l o g i e$ \& Réanimation Respiratoires, UPRES "Maladies vasculaires et pulmonaires", Hôpital Antoine Béclère AP-HP, Clamart - France. łInstitut de Génétique et de Biologie Moléculaire et Cellulaire, CNRS, INSERM, Université L. Pasteur de Strasbourg, BP 10142 - 67404 ILLKIRCH CEDEX - France

Primary pulmonary hypertension is a progressive and often fatal human disorder that results from an increase in pulmonary blood pressure associated with abnormal vascular proliferation. The use of dexfenfluramine increases the risk of pulmonary hypertension in humans and its active metabolite is a selective serotonin $5-\mathrm{HT}_{2 \mathrm{~B}}-$ receptor agonist. We have therefore investigated a possible contribution of $5-\mathrm{HT}_{2 \mathrm{~B}}$-receptor to pulmonary hypertension pathogenesis. Using the chronic hypoxic mice model of pulmonary hypertension, we found that the hypoxia-dependent increase in pulmonary blood pressure and lung remodeling are associated with a rise in vascular proliferation, elastase activity and TGF-B level and these parameters are potentiated by dexfenfluramine treatment. By contrast, hypoxic mice with genetically or pharmacologically inactive $5-\mathrm{HT}_{2 \mathrm{~B}}$ receptors manifested no change in any of these parameters. In both humans and mice, pulmonary hypertension is associated with a striking increase in $5-\mathrm{HT}_{2 \mathrm{~B}}$ receptor expression in pulmonary arteries. These data show that activation of 5-HT receptors is a limiting step in the development of pulmonary hypertension. 
Primary pulmonary hypertension (P-PH) is a rare condition characterized by an elevation in pulmonary arterial pressure that is associated with irreversible pulmonary remodeling ${ }^{1,2}$. The hypoxia-induced changes in pulmonary artery pressure that result from vascular cell proliferation recapitulate, at least in part, the changes observed in PPH indicating that it is a relevant model for this pathology ${ }^{3,4}$. Several studies have suggested a role for serotonin (5-hydroxytryptamine, 5-HT) in the aetiology of $\mathrm{PH}^{5-7}$. In response to hypoxia, 5-HT is released from pulmonary neuroendocrine cells and neuroepithelial bodies distributed throughout the airways. A sustained increase of 5-HT is observed in the plasma of $\mathrm{PH}$ patients ${ }^{8,9}$. Furthermore, isolated smooth muscle and endothelial cells from pulmonary arteries express mRNAs for $5-\mathrm{HT}_{1 \mathrm{~B}}, 5-\mathrm{HT}_{2 \mathrm{~A}}, 5-\mathrm{HT}_{7}$ and $5-\mathrm{HT}_{2 \mathrm{~B}}$ receptors ${ }^{10}$. As a potent pulmonary vasoconstrictor ${ }^{5}, 5-\mathrm{HT}$ might have a dual effect on pulmonary circulation, contributing to both hypoxia-induced acute vasoconstriction and chronic vascular remodeling by activating its cognate receptors.

When used for more than 3 months, the appetite-suppressants (anorexigens) derived from amphetamines, fenfluramine and dexfenfluramine (DF), increase the risk of developing $\mathrm{PH}$ by a factor of between 3.7 to 23 -fold depending on the study consulted ${ }^{11,12}$. DF binds weakly to the 5- $\mathrm{HT}_{2 \mathrm{~A}}, 5-\mathrm{HT}_{2 \mathrm{~B}}$, and $5-\mathrm{HT}_{2 \mathrm{C}}$ receptors. However, the main metabolite of DF, norDF, behaves as a high affinity ligand for 5$\mathrm{HT}_{2 \mathrm{~B}}$ receptors $\left(5-\mathrm{HT}_{2 \mathrm{~B}} \mathrm{R}\right)$ and more moderately for $5-\mathrm{HT}_{2 \mathrm{~A}}$ and $5-\mathrm{HT}_{2 \mathrm{C}}$ receptors ${ }^{13}$. Furthermore, in cells expressing recombinant $5-\mathrm{HT}_{2 \mathrm{~B}} \mathrm{R}$, norDF acts as a potent agonist, which stimulates phosphoinositide hydrolysis, intracellular $\mathrm{Ca}^{2+}$ levels and the mitogenactivated protein (MAP) kinase cascade ${ }^{13}$. MAPkinase activation mediates the mitogenic actions of 5-HT, which is accomplished via the $5-\mathrm{HT}_{2 \mathrm{~B}} \mathrm{R}$ by stimulating $\mathrm{p} 60^{\text {Src }}$ and $\mathrm{p} 21^{\text {ras }}$ signaling ${ }^{14,15}$. Functionally and immunohistologically, $5-\mathrm{HT}_{2 \mathrm{~B}} \mathrm{Rs}$ are detected in lung endothelial and smooth muscle cells of various species including humans ${ }^{16,17}$. We have therefore tested the hypothesis of a direct implication of 5$\mathrm{HT}_{2 \mathrm{~B}} \mathrm{Rs}$ in the development of $\mathrm{PH}$. This work has revealed that $5-\mathrm{HT}_{2 \mathrm{~B}} \mathrm{R}$ expression is significantly increased in $\mathrm{PH}$ and that the blockade of $5-\mathrm{HT}_{2 \mathrm{~B}} \mathrm{Rs}$ using two independent approaches prevents completely the development of hypoxia-induced $\mathrm{PH}$ in mice.

\section{The hypoxia-induced rise in pulmonary artery pressure is $\mathbf{5 - H T _ { 2 B }} \mathbf{R}$-dependent.}

We first assessed the effect of a chronic exposure of mice to hypoxia $\left(10 \% \mathrm{O}_{2}, 5\right.$ weeks $)$ by monitoring their hemodynamic parameters. When compared with mice maintained under normoxic conditions, control mice (129PAS wild-type, ${ }^{+/+}$) exposed to hypoxia exhibited gradual increases in right ventricular systolic pressure (RVSP) such that, after 5 weeks, values were higher than those recorded after 2 weeks (not shown). After 5 weeks under hypoxia, the mean RVSP was significantly higher $(165 \%$ of the control value) than in normoxic mice (Fig. 1a).

We recently generated mutant mice by homologous recombination of the 5$\mathrm{HT}_{2 \mathrm{~B}} \mathrm{R}$ gene $\left(5-\mathrm{HT}_{2 \mathrm{~B}}{ }^{-/}\right)$. These mutant mice display cardiac defects leading to partial embryonic lethality ${ }^{18}$. Living adult $5-\mathrm{HT}_{2 \mathrm{~B}}{ }^{-/-}$mice have normal systolic blood pressure despite their dilated cardiomyopathy ${ }^{19}$. In a first attempt to evaluate a potential role for the 5- $\mathrm{HT}_{2 \mathrm{~B}} \mathrm{R}$ in $\mathrm{PH}$, we treated $5-\mathrm{HT}_{2 \mathrm{~B}}{ }^{-/-}$adult mice with the same hypoxic protocol as described above. Surprisingly, none of the $5-\mathrm{HT}_{2 \mathrm{~B}}{ }^{-/-}$mice exposed to hypoxia exhibited an increase in RVSP (Fig. 1a). The right-ventricle weight over left-ventricle-plusseptum weight ratio $(\mathrm{RV} / \mathrm{LV}+\mathrm{S})$ was significantly increased only in ${ }^{+/+}$mice exposed to hypoxia, reasserting the hypoxia-induced modifications of RVSP in ${ }^{+/+}$mice and the absence of hypoxia-induced responses of $5-\mathrm{HT}_{2 \mathrm{~B}}{ }^{-/-}$mice (Table I); the basal value of 5- 
$\mathrm{HT}_{2 \mathrm{~B}}{ }^{-/-}$mice, higher than in control animals, reflects directly their left ventricle dysfunctions. Our results indicate that the $5-\mathrm{HT}_{2 \mathrm{~B}} \mathrm{R}$ is necessary for the chronic hypoxic response leading to increased RVSP.

Since DF increases the risk of developing PH in humans ${ }^{12}$, we evaluated the putative effect of "therapeutic" concentrations of DF in hypoxia-induced increases in pulmonary pressure in mice. The chronic exposure of ${ }^{+/+}$mice to hypoxia and DF further increased significantly the RVSP $(229 \%$ and $138 \%$ of normoxic and hypoxic values respectively) (Fig. 1a). The $\mathrm{RV} / \mathrm{LV}+\mathrm{S}$ was also significantly increased in ${ }^{+++}$mice exposed to hypoxia in the presence of DF when compared with both normoxic and hypoxic ${ }^{+/+}$mice (Table I). Importantly, hypoxia in the presence of DF generated high lethality: out of 20 mice treated, four were found dead from obvious signs of $\mathrm{PH}$. Furthermore, chronic exposure of $5-\mathrm{HT}_{2 \mathrm{~B}}{ }^{-/-}$mice to DF in the presence of hypoxia or normoxia had no significant effect on the RVSP (Fig. 1a) or on the RV/LV+S (Table I).

To validate these observations, we used an independent pharmacological approach. We challenged ${ }^{+/+}$mice with the recently developed compound, RS-127445 (2-amino-4- (4-fluoronaphth-1-yl)-6-isopropylpyrimidine, RS). This compound has a sub-nanomolar affinity for the $5-\mathrm{HT}_{2 \mathrm{~B}} \mathrm{R}\left(\mathrm{pK}_{\mathrm{i}}=9.5 \pm 0.1\right)$ and potently antagonizes the $5-\mathrm{HT}_{2 \mathrm{~B}} \mathrm{R}$ with a 1,000 fold selectivity over numerous other molecules including all known 5-HT receptors and transporter ${ }^{20}$. In complete agreement with our first observations on $5-\mathrm{HT}_{2 \mathrm{~B}}{ }^{-/-}$mice, simultaneous exposure of ${ }^{+/+}$mice to hypoxia in the presence of RS prevented an increase in RVSP (Fig. 1a). Furthermore, chronic exposure to RS in the presence of normoxia in ${ }^{+/+}$mice and of hypoxia or normoxia in $5-\mathrm{HT}_{2 \mathrm{~B}}{ }^{-/-}$ mice had no significant effects on the RVSP (Fig. 1a). Combined, these data support the initial findings that the $5-\mathrm{HT}_{2 \mathrm{~B}} \mathrm{R}$ is required for the chronic hypoxia-induced increase in RVSP.

\section{The histological remodeling triggered by hypoxia requires $5-H^{-} T_{2 B} R$.}

Exposure to hypoxia dramatically increases structural remodeling of the pulmonary arteries resulting from vascular cell proliferation that generates most of the RVSP increase $^{21}$. Chronic hypoxic exposure of ${ }^{+/+}$mice induced obvious modifications of lung morphology revealed by the degree of pulmonary artery muscularization (Fig. 1b-2ghi); the statistical analysis of lung morphology revealed that increased RVSP is associated with a significant increase in pulmonary artery muscularization; DF further and significantly enhanced this remodeling (Fig. 1b-2jklnp). Alternatively, no significant modification of the pulmonary artery muscularization could be revealed in hypoxic 5$\mathrm{HT}_{2 \mathrm{~B}}{ }^{-/-}$mice with, or without, RS or DF, or following RS treatment of hypoxic ${ }^{+/+}$mice (Fig. 1b-2def). In addition, staining of lung sections revealed that the hyperplasic cell population consisted mainly of smooth muscle cells as they expressed smooth musclespecific actin (Fig. 2n) and also demonstrated the presence of $5-\mathrm{HT}_{2 \mathrm{~B}} \mathrm{Rs}$ expression in hypoxic ${ }^{+/+}$mice (Fig. 2 p).

To get further insights into the molecular pathways involved in hypoxic responses, we developed isolated lung vasculature explant culture of hypoxia- (or normoxia-) treated mice. Compared with normoxic animals, basal thymidine incorporation was significantly increased (1.95 times basal) in the lung vessels from hypoxic $^{+/+}$mice (Fig. 3a). This increase was completely prevented in the hypoxic lungs of ${ }^{+/+}$mice treated by RS, while DF treatment significantly potentiated DNA synthesis (2.5 times vs. basal and 1.3 times vs. hypoxia). By contrast, lung vessels of $5-\mathrm{HT}_{2 \mathrm{~B}}{ }^{-/-}$ 
mice did not exhibit any hypoxia-induced nor DF-potentiated increase in DNA synthesis. These data support the notion that $5-\mathrm{HT}_{2 \mathrm{~B}} \mathrm{R}$ is a limiting factor in chronic hypoxia-induced pulmonary vascular proliferation.

Progression of PH is associated with increased serine elastase activity ${ }^{22}$, which can activate storage sites for growth factors such as basic fibroblast growth factor and transforming growth factor-beta (TGF- $\beta)^{23}$. Supernatants of lung vessels cultures from hypoxic ${ }^{+/+}$mice revealed a significant increase in elastase activity (11.6 times basal) and in TGF- $\beta$ levels (3.9 times basal), both of which were further potentiated after DF treatment (16.9 and 4.9 times basal, respectively). Conversely, there was no detectable change in hypoxia-induced elastase activity and TGF- $\beta$ levels in supernatants from vessels of hypoxic ${ }^{+/+}$mice in the presence of $\mathrm{RS}$ or of $5-\mathrm{HT}_{2 \mathrm{~B}}{ }^{-/-}$mice after either treatment (Fig. 3b-c). These results indicate that both hypoxia-increased remodeling factors, pulmonary elastase activity and TGF- $\beta$ levels, are dependent on $5-\mathrm{HT}_{2 \mathrm{~B}} \mathrm{R}$ activity.

\section{The 5-HT ${ }_{2 \mathrm{~B}} \mathrm{R}$ is not involved in acute hypoxia-dependent vasoconstriction}

Acute hypoxic responses are important triggers in the establishment of chronic $\mathrm{PH}^{24}$ and thus, the limiting functions of $5-\mathrm{HT}_{2 \mathrm{~B}} \mathrm{R}$ in chronic response to hypoxia could rely on direct acute effects of hypoxia on $5-\mathrm{HT}_{2 \mathrm{~B}} \mathrm{R}$. We therefore investigated whether 5$\mathrm{HT}_{2 \mathrm{~B}} \mathrm{R}$ participates in acute responses to hypoxia. Following repeated acute hypoxic stimuli $^{25}$, we observed a moderate but significant increase in RSVP in both ${ }^{+/+}$and 5 $\mathrm{HT}_{2 \mathrm{~B}}{ }^{-/-}$mice, indicating that $5-\mathrm{HT}_{2 \mathrm{~B}} \mathrm{Rs}$ are not required for short-term increases in RVSP (Fig. 3d). The result of the same experimental setup in the presence of DF was also independent of 5- $\mathrm{HT}_{2 \mathrm{~B}} \mathrm{Rs}$. Plasma DF and norDF measurements (Supplementary Data) clearly demonstrated that short term exposure is not sufficient enough to produce significant amounts of norDF and confirmed that the effect of DF is mediated by its metabolite norDF at $5-\mathrm{HT}_{2 \mathrm{~B}} \mathrm{R}$. When testing for elastase activity following the same acute hypoxic stimuli, we observed a significant increase in elastase activity in ${ }^{+/+}$but not in $5-\mathrm{HT}_{2 \mathrm{~B}}{ }^{-/-}$mice lungs (Fig. 3e), indicating that effectors of the $5-\mathrm{HT}_{2 \mathrm{~B}} \mathrm{R}$ (after chronic hypoxia) are regulated by acute hypoxic stimulus. These results clearly suggest that $5-\mathrm{HT}_{2 \mathrm{~B}} \mathrm{R}$ influence is not at the level of acute vasoconstrictive responses but rather that of the signaling mechanisms that lead to the expression of factors important in vascular remodeling.

\section{Pulmonary artery 5-HT ${ }_{2 B} R$ expression is increased during $\mathbf{P H}$.}

The absence of 5-HT transporter (5-HTT) in pulmonary vessels reduces chronic hypoxia-induced $\mathrm{PH}^{26}$. We tested therefore the 5-HT uptake activity in cultures of lung vasculature. In ${ }^{+/+}$hypoxic vessels, we observed a trend toward a decrease in 5-HT uptake while, in $5-\mathrm{HT}_{2 \mathrm{~B}}{ }^{-/-}$mice, an increase in basal 5-HTT activity was detected. The 5-HT uptake activity was almost entirely blocked by DF in both ${ }^{+/+}$and $5-\mathrm{HT}_{2 \mathrm{~B}}{ }^{-/-}$ hypoxic vessels (Fig. 4a). From this latter observation, it can be concluded that defective 5-HT uptake is not sufficient to induce pulmonary hypertensive response in 5$\mathrm{HT}_{2 \mathrm{~B}}{ }^{-/-}$mice.

To elucidate how 5-HT receptors control hypoxic responses, we investigated their expression in $\mathrm{PH}$ lung vasculature. While $5-\mathrm{HT}_{2 \mathrm{~A}} \mathrm{R}$ expression was not modified by exposure of ${ }^{+/+}$mice to hypoxia and $\mathrm{DF}, 5-\mathrm{HT}_{1 \mathrm{~B}} \mathrm{R}$ expression increased $1.75 \pm 0.1$ times $(\mathrm{P}<0.01, \mathrm{n}=6)$, though this could be prevented by RS. More strikingly, hypoxia itself and in the presence of DF or of RS increased significantly the mean $5-\mathrm{HT}_{2 \mathrm{~B}} \mathrm{R}$ - 
specific binding ( $2.6 \pm 0.2$ times, $2.9 \pm 0.2$ times, and $2.2 \pm 0.1$ times, respectively) in ${ }^{+/+}$mice (Fig. 4b). Furthermore, we observed significant $(P<0.0001)$ correlations between the entire individual 5- $\mathrm{HT}_{2 \mathrm{~B}} \mathrm{R}$ binding and RVSP values (Fig. 4c) and between the basal thymidine incorporation indexes in lungs and both $5-\mathrm{HT}_{2 \mathrm{~B}} \mathrm{R}$ binding and RVSP values but only in mice submitted to hypoxia and in the presence of active 5$\mathrm{HT}_{2 \mathrm{~B}} \mathrm{R}$ (Fig. 4de). These correlations further substantiate the evidence that $5-\mathrm{HT}_{2 \mathrm{~B}} \mathrm{R}$ is required for a hypoxic increase in RVSP and thus for the $\mathrm{PH}$ pathogenesis. Accordingly, a preliminary screening of 5-HT receptors expression in biopsies of human pulmonary artery indicates that the numbers of binding sites are markedly higher in $\mathrm{PH}$ patients than in non- $\mathrm{PH}$ patients for $5-\mathrm{HT}_{1 \mathrm{~B}} \mathrm{R}$ and $5-\mathrm{HT}_{2 \mathrm{~B}} \mathrm{R}(1.98 \pm 0.05$ times and $4.32 \pm 0.76$ times, respectively, $P<0.01, \mathrm{n}=5)$, but not for $5-\mathrm{HT}_{2 \mathrm{~A}} \mathrm{R}(0.99 \pm 0.10$ times, $\mathrm{n}=5$, NS).

\section{Discussion}

The identification of specific pathways involved in the development of $\mathrm{PH}$ is dependent upon pharmacological, transgenic or targeted gene disruption approaches on animal models. The only commonly utilized mouse model of $\mathrm{PH}$ is the chronic hypoxic case. Mice with genetic ablation of known vasodilators, endothelial NO synthase ${ }^{27}$ or prostacyclin receptor ${ }^{28}$, appear more sensitive to hypoxia. By contrast, targeted disruption of genes involved in pulmonary vasoconstriction appears to reduce hypoxiainduced $\mathrm{PH}$ in mice. Mice deficient for $5-\mathrm{HT}_{1 \mathrm{~B}} \mathrm{R}\left(5-\mathrm{HT}_{1 \mathrm{~B}}{ }^{-/-}\right)$developed less severe $\mathrm{PH}$ and vascular remodeling than ${ }^{+/+}$mice ${ }^{29}$. The $5-\mathrm{HT}_{1 \mathrm{~B}} \mathrm{Rs}$ play a role in the development of $\mathrm{PH}$ via enhanced 5- $\mathrm{HT}_{1 \mathrm{~B}} \mathrm{R}$-mediated contraction of the pulmonary arterial circulation ${ }^{24}$, but this activity is not limiting in the development of $\mathrm{PH}$ since $5-\mathrm{HT}_{1 \mathrm{~B}}{ }^{-/-}$mice are still responding to hypoxia ${ }^{29}$. However, using the chronic hypoxic mice model, we are able to demonstrate the complete absence of $\mathrm{PH}$ and vascular remodeling in hypoxic 5$\mathrm{HT}_{2 \mathrm{~B}} \mathrm{R}$-inactive mice indicating that $5-\mathrm{HT}_{2 \mathrm{~B}} \mathrm{Rs}$ are limiting for chronic hypoxic responses, though independently of acute hypoxic vasoconstrictive responses.

Although congenital cardiac defects increase the risk of developing $\mathrm{PH}^{30}, \mathrm{LV}$ dysfunction in $5-\mathrm{HT}_{2 \mathrm{~B}}{ }^{-/}$mice ${ }^{19}$ could impact on the cardiovascular remodeling responses, but this can be ruled out in $5-\mathrm{HT}_{2 \mathrm{~B}}{ }^{-{ }_{-}}$mice since: (i) The cardiac phenotype of $5-\mathrm{HT}_{2 \mathrm{~B}}{ }^{-/-}$mice is characterized by $\mathrm{LV}$ dysfunctions but no apparent $\mathrm{RV}$ alterations ${ }^{19}$. (ii) Basal pulmonary pressure in $5-\mathrm{HT}_{2 \mathrm{~B}}{ }^{-/-}$mice is indistinguishable from ${ }^{+/+}$mice. (iii) No PH developed in ${ }^{+/+}$mice exposed to chronic hypoxia in the presence of $5-\mathrm{HT}_{2 \mathrm{~B}} \mathrm{R}$ antagonist (RS), clearly demonstrating that the activation of $5-\mathrm{HT}_{2 \mathrm{~B}} \mathrm{Rs}$ is required for hypoxia-induced $\mathrm{PH}$ independently of any prior cardiac phenotype. Furthermore, some mutant mice strains developing cardiomyopathy such as mice lacking natriuretic peptide receptor A have an increased sensitivity to hypoxia of their lung vasculature ${ }^{31}$. Combined, these observations strongly support the conclusion that the absence of hypoxic response of 5- $\mathrm{HT}_{2 \mathrm{~B}}{ }^{-/-}$mice cannot be attributed to their cardiomyopathy.

Some 5-HTT blockers and substrates such as DF are implicated in $\mathrm{PH}$ pathogenesis, while others, e.g. m-CPP are not ${ }^{32,33}$. The DF effect on PH was initially suggested to result from 5-HTT inhibition since a change in platelet 5-HT uptake could explain the raised 5-HT plasma level observed in PH patients ${ }^{7-9,34}$. Other 5-HTT blockers, however, such as 5-HT-specific-reuptake-inhibitors or tricyclic antidepressants, have not been associated with pulmonary pathology. Upon $5-\mathrm{HT}_{2 \mathrm{~B}} \mathrm{Rs}$, the $\mathrm{EC}_{50}$ of DF is over $1 \mu \mathrm{M}$, but the major metabolite of DF, norDF, which acts as a potent agonist with nanomolar affinity $\left(\mathrm{pEC}_{50}=8.06 \pm 0.16\right)^{13}$, requires chronic 
treatments to be detected (Supplementary Data). Other high affinity agonists at 5$\mathrm{HT}_{2 \mathrm{~B}} \mathrm{Rs}$ do not appear to be associated with $\mathrm{PH}$ in humans ${ }^{33}$ and thus a combinatorial effect at different receptors with transporters may be required for $\mathrm{PH}$ development. However, the significant DF potentiation of a hypoxia-dependent increase in RVSP and remodeling is completely eliminated in $5-\mathrm{HT}_{2 \mathrm{~B}}{ }^{-\gamma}$ mice. Since the 5 -HT uptake activity is largely reduced in lungs of $5-\mathrm{HT}_{2 \mathrm{~B}}{ }^{-/-}$mice exposed to hypoxia and $\mathrm{DF}$ and which do not develop PH, blocking 5-HT uptake activity is not sufficient to trigger hypoxiadependent PH. Consistent with this observation is the fact that mice deficient for 5-HTT $\left(5-\mathrm{HTT}^{-/}\right)$are still responsive to hypoxia though they develop less severe $\mathrm{PH}$ and vascular remodeling when compared with the ${ }^{+/+}$mice ${ }^{26}$.

In animal models, DF does not induce $\mathrm{PH}$ per se, but it can potentiate hypoxiainduced PH: dogs chronically treated with DF revealed increased pulmonary vascular resistance upon exposure to hypoxia ${ }^{35}$. Rats exposed to a 4-week DF treatment in normoxia followed by 2-week hypoxia developed stronger $\mathrm{PH}$ than the controls, suggesting also that DF pre-treatment promotes the development of $\mathrm{PH}$ in rats ${ }^{36}$. The recently proposed mechanism by which DF-like drugs may promote pulmonary vascular remodeling by stimulating 5-HTT expression ${ }^{37}$ cannot fully explain why patients developing PH after DF treatment reveal the same proportion of 5-HTT promoter polymorphism as do the PH patients in general. The lack of a higher incidence of the 5HTT polymorphism in the group that ingested DF and developed PH suggests also that other factors are required for DF-induced $\mathrm{PH}$ to develop ${ }^{38}$. In our hypoxic mouse model, the need of active 5- $\mathrm{HT}_{2 \mathrm{~B}} \mathrm{Rs}$ to reveal the DF potentiating action demonstrates that, although a contribution of 5-HTT to DF effects is likely, the DF potentiation of hypoxia-induced $\mathrm{PH}$ requires $5-\mathrm{HT}_{2 \mathrm{~B}} \mathrm{R}$ activation.

A lung vascular proliferative response occurs in response to 5-HT, but it remains debatable whether the 5-HT mitogenic effect is initiated through a $5-\mathrm{HT}_{2} \mathrm{R}$ or the 5HTT, or both ${ }^{39,40}$. The observation that lung tissue from PH patients without the long 5HTT promoter polymorphism revealed proliferative response to 5-HT higher than normal ${ }^{37}$, indicates also that other components of the 5-HT pathway, such as receptors or downstream effectors, are needed to promote $\mathrm{PH}^{38}$. In lung vascular cells, 5-HT induced DNA synthesis seemed dependent on the 5-HTT, since it was prevented by some 5-HTT inhibitors, but unaltered by ketanserin, a 5- $\mathrm{HT}_{2 \mathrm{~A}} \mathrm{R}$ antagonist ${ }^{39}$. However, in lung smooth muscle cells, the calcium transients due to 5-HT persisted in $\mathrm{Na}^{+}$-free conditions (no 5-HT uptake) and 5-HTT inhibitors were still inhibiting 5-HT-induced mitogenesis ${ }^{41}$. Thus, the $5-\mathrm{HT}_{2} \mathrm{R}$ rather than the 5-HTT initiated the 5-HT effect, indicating that 5-HTT inhibitors have $5-\mathrm{HT}_{2} \mathrm{R}$ antagonist properties as recently confirmed ${ }^{42}$. In contrast to what is observed in hypoxic ${ }^{+/+}$mice lung vasculature, the total lack of increased basal thymidine incorporation in hypoxic $5-\mathrm{HT}_{2 \mathrm{~B}}{ }^{-/}$mice tissue indicates an absolute requirement of $5-\mathrm{HT}_{2 \mathrm{~B}} \mathrm{R}$ for chronic hypoxia-induced mitogenesis. This finding is validated by the complete prevention of proliferation and vascular remodeling upon treatment of hypoxic ${ }^{+/+}$mice with the $5-\mathrm{HT}_{2 \mathrm{~B}} \mathrm{R}$ antagonist RS. Although a direct contribution of $5-\mathrm{HT}_{2 \mathrm{~B}} \mathrm{R}$ to the chronic hypoxia-induced mitogenesis remains to be firmly established, it is likely since (i) we have previously reported that activation of $5-\mathrm{HT}_{2 \mathrm{~B}} \mathrm{R}$ can initiate cell cycle progression ${ }^{15}$ and (ii) the basal thymidine incorporation indexes in lungs are significantly correlated with both $5-\mathrm{HT}_{2 \mathrm{~B}} \mathrm{R}$ binding and RVSP values, only when mice are submitted to hypoxia and in the presence of active $5-\mathrm{HT}_{2 \mathrm{~B}} \mathrm{R}$. Other serotonergic molecules ${ }^{5,26}$ may indeed participate in the hypoxic mitogenic process of $\mathrm{PH}$, but our animal model provides the first direct evidence that 5 - 
$\mathrm{HT}_{2 \mathrm{~B}} \mathrm{R}$ activation is a limiting, non-redundant step, required for the hypoxia-induced vascular proliferation in mice.

We report that the $5-\mathrm{HT}_{2 \mathrm{~B}} \mathrm{R}$ effect is not at the level of acute vasoconstrictive responses but rather the signaling mechanisms that control factors important in vascular remodeling such as elastase. $\mathrm{PH}$ vascular remodeling is associated with increased serine elastase activity working either directly or via activation of matrix metalloproteinases, and elastase inhibitors can reverse advanced pulmonary vascular disease ${ }^{43}$. The matrix metalloproteinases are a family of proteases implicated in extracellular matrix turnover and hence contribute to vascular smooth muscle and endothelial cell migration and proliferation ${ }^{22}$. Furthermore, elastase can increase TGF- $\beta$ availability, optimizing the mitogenic response in cultured vascular cells ${ }^{23}$. Our data indicate that $5-\mathrm{HT}_{2 \mathrm{~B}} \mathrm{Rs}$ are crucial for hypoxia-induced remodeling factors by their regulation of elastase activity and TGF expression in mice lung vasculature. In humans, heterozygous mutations within the bone morphogenetic protein type II receptor (BMPR-II) gene of the TGF- $\beta$ cell-signaling superfamily have recently been identified in $25 \%$ of sporadic and $55 \%$ of familial cases of $\mathrm{PH}^{3}$. The low penetrancy of these mutations (10-20\%) suggests a need for other factors (genetic, environmental, pathologic) in $\mathrm{PH}$ pathogenesis, see for review 3 . Recent evidence has shown that both TGF- $\beta$ and BMPs proliferative functions are altered in smooth muscles from $\mathrm{PH}$ patients ${ }^{44}$. In familial forms of $\mathrm{PH}$, the primary event appears to be vascular-cell proliferation ${ }^{3}$. However, hypoxia is a preponderant environmental factor that generates $\mathrm{PH}$ in humans ${ }^{4}$. Vascular proliferative changes, which may represent adaptive (maladaptive) responses to this exogenous stimulus are associated with increased $5-\mathrm{HT}_{2 \mathrm{~B}} \mathrm{R}$ expression and require activation of $5-\mathrm{HT}_{2 \mathrm{~B}} \mathrm{Rs}$. In complete agreement with the mice model is the increase in $5-\mathrm{HT}_{2 \mathrm{~B}} \mathrm{R}$ expression found in lungs of $\mathrm{PH}$ patients. Furthermore, this finding could explain the proliferative response to 5-HT, higher than normal, observed in $\mathrm{PH}$ patients ${ }^{37}$ and independent of their 5-HTT genotype ${ }^{38}$.

In conclusion, our work supports the scheme presented (Fig. 5) in which 5$\mathrm{HT}_{2 \mathrm{~B}} \mathrm{Rs}$ hypoxia-dependent increased expression has a central role in pulmonary hypertensive responses in mice. Subsequently, active $5-\mathrm{HT}_{2 \mathrm{~B}} \mathrm{Rs}$ are an absolute necessity for lung vascular proliferation, elastase- and TGF- 3 -dependent remodeling. In addition, DF action at 5-HTT acts as an amplifier of norDF agonist action at 5- $\mathrm{HT}_{2 \mathrm{~B}} \mathrm{Rs}$. All these activities contribute toward increases in RVSP and PH pathogenesis in mice. Similar increased 5-HT receptor expression in lungs of $\mathrm{PH}$ patients suggests that comparable mechanisms exist in humans and indicate that $5-\mathrm{HT}_{2 \mathrm{~B}} \mathrm{R}$ expression may be used as a diagnostic criterion for susceptibility to $\mathrm{PH}$. The $5-\mathrm{HT}_{2 \mathrm{~B}} \mathrm{Rs}$ should now be considered as a potential target for developing new treatments of $\mathrm{PH}$ in humans. 


\section{'Methods'. Hypoxia.}

The $5-\mathrm{HT}_{2 \mathrm{~B}} \mathrm{R}$ mutant mice $\left(5-\mathrm{HT}_{2 \mathrm{~B}}{ }^{-/}\right)$were generated in the 129PAS pure genetic background that was used as controls $\left({ }^{+/+}\right)$. Mice 6 weeks of age $(20-25 \mathrm{~g})$ were randomly divided into two groups of 5 males and 5 females, one maintained in room air $\left(21 \% \mathrm{O}_{2}\right)$ and the other exposed to hypoxia, for 2 or 5 weeks. Normobaric hypoxic chambers $\left(21-23^{\circ} \mathrm{C}\right)$ maintained by $5.5 \mathrm{l} / \mathrm{min}$ flow of hypoxic air $\left(10 \% \mathrm{O}_{2}, 90 \% \mathrm{~N}_{2}\right)$ were opened twice a day for 15 min for cage cleaning, food and water supplies. The oxygen concentrations were monitored continuously using blood gas analyzers and soda lime was used to reduce the concentration of carbon dioxide. Normoxic mice were kept in the same room with the same 12/12 light-dark cycle. The vehicle, RS at $1 \mathrm{mg} / \mathrm{kg} / \mathrm{day}$ or DF at the "therapeutic" dose of $2.5 \mathrm{mg} / \mathrm{kg} /$ day was delivered by miniosmotic pump (Alzet) at the beginning of the hypoxic (or normoxic) treatment. Acute hypoxic experiments consisted of the exposure of conscious mice to five successive hypoxic $\left(10 \% \mathrm{O}_{2}\right)$ challenges ${ }^{25}$, hemodynamic variables were recorded first while the animal was breathing air, then after 10 min of exposure to the hypoxic gas mixture and finally 20 min after returning to normoxia. Five similar successive hypoxic challenges were repeated for each mouse. All animal care and procedures were in accordance with institutional guidelines and European regulations.

\section{Cardiovascular evaluations.}

Mice were anesthetized with intraperitoneal ketamine hydrochloride $(60 \mathrm{mg} / \mathrm{kg})$ and xylazine $(8 \mathrm{mg} / \mathrm{kg})$. Right ventricular systolic pressure (RVSP) was measured by insertion into the right ventricle of a 26-gauge needle connected to a pressure transducer. After a blood sample was collected by cardiac puncture for DF and norDF measurements (Supplementary Data), the pulmonary artery was cannulated through an incision in the right ventricle and perfused with Earle's balanced salt solution $\left(37^{\circ} \mathrm{C}, 20\right.$ $\mathrm{cm} \mathrm{H}_{2} \mathrm{O}$ pressure). The heart and lungs were removed en bloc, and the airways were distended with 10\% formaldehyde solution and fixed for 3 days. For the assessment of right ventricular hypertrophy, weights of the right ventricular free wall (RV) and the left ventricle together with the septum $(\mathrm{LV}+\mathrm{S})$ were measured separately. For morphometric analysis, one sagittal section ( $5 \mu \mathrm{m}$ in thickness) was obtained from each left lung and after paraffin embedding, stained with hematoxylin-phloxin-saffron and orcein-picroindigo-carmine. In each section, a total of 55 to 65 vessels was examined. Pulmonary arteries $(25-100 \mu \mathrm{m})$ associated with an airway distal to the respiratory bronchiole were counted. The arteries were considered as muscularized if they possessed a distinct double-elastic lamina visible for the complete diameter in the vessel cross-section ${ }^{29}$. If they were seen in smaller part of the arterial circumference, they were recorded as partially muscular arteries and if absent as non-muscular arteries. These observations were done in a blinded setup $v s$. genotypes and treatments.

\section{Explants.}

Lung vascular bed around pulmonary arteries was collected and prepared for organ culture $^{45}$. Each explant (10-15 mg) was maintained in DMEM supplemented with 5HT-depleted serum (10\%) for a maximal period of 3 days. Fragments (1-2 mg each) seeded onto tissue culture vessels for 24-h were washed with HBSS and grown for 24-h in serum-free medium $\{\mathrm{DMEM} / \mathrm{F}-12(1: 1)$ with $5 \mu \mathrm{g} / \mathrm{ml}$ insulin, $5 \mu \mathrm{g} / \mathrm{ml}$ transferrin, 30 $\mathrm{nM}$ selenium, $20 \mathrm{nM}$ progesterone, and $100 \mu \mathrm{M}$ putrescine $\}$ before thymidine 
incorporation was performed within next $12-\mathrm{h}^{14}$. Conditioned media from all cultures were collected and stored. For elastolytic activities, conditioned media were incubated at $37^{\circ} \mathrm{C}$ with $\left[{ }^{3} \mathrm{H}\right]$-elastin ${ }^{43}$. TGF- $\beta$ was also measured in conditioned media with an ELISA using a pan-specific anti-TGF- $\beta$ polyclonal antibody (R\&D Systems catalog \# AB-100-NA). To measure 5-HT uptake, after incubation for 1 min with $10^{-7} \mathrm{M}\left[{ }^{3} \mathrm{H}\right]-5$ HT binoxalate, each lung fragment was lysed by addition of $0.1 \mathrm{~N} \mathrm{NaOH}$ and radioactivity was counted. Specific 5-HT uptake assessed as the difference between total uptake and uptake in the presence of $1 \mu \mathrm{M}$ paroxetine, was expressed in picomoles of 5-HT taken up per milligram of protein per minute. Measurements of the 5-HT receptor expression was performed using a 5- $\mathrm{HT}_{2 \mathrm{~B}} \mathrm{R}$-specific tritiated radioligand (LY266070), a 5-HT ${ }_{1 B} \mathrm{R}$-specific iodinated radioligand $\left({ }^{125} \mathrm{I}-\mathrm{GTI}\right)$, or for $5-\mathrm{HT}_{2 \mathrm{~A}} \mathrm{R}$ the fraction of $5-\mathrm{HT}_{2} \mathrm{R}$-specific iodinated radioligand $\left({ }^{125} \mathrm{I}-\mathrm{DOI}\right)$ insensitive to LY266070 as previously described ${ }^{18}$.

\section{Statistics.}

The reported data represent the mean of individual values \pm SEM $(n=$ number of individuals at the end of treatments as indicated in the text). Comparisons were performed using the non-parametric Kruskal-Wallis test. All statistical difference vs. normoxic untreated control values is indicated by an asterisk and $v s$. chronic hypoxia values by a cross and significance was set at $P<0.05$. This level of significance also applies to correlation between individual values, assessed by Kendall rank coefficients. For the groups of pulmonary artery muscularization, statistical comparisons were made by one way ANOVA. When statistical significance was attained $(P<0.05)$, difference between groups was established using the Newman-Keuls multiple comparison test.

\section{References}

1. Rabinovitch, M. Pulmonary hypertension: updating a mysterious disease. Cardiovasc. Res. 34, 268-272. (1997).

2. Rubin, L.J. Cellular and molecular mechanisms responsible for the pathogenesis of primary pulmonary hypertension. Pediatr. Pulmonol. Suppl. 18, 194-197. (1999).

3. Loscalzo, J. Genetic clues to the cause of primary pulmonary hypertension. N. Engl. J. Med. 345, 367-371. (2001).

4. Tucker, A. \& Rhodes, J. Role of vascular smooth muscle in the development of high altitude pulmonary hypertension: an interspecies evaluation. High Alt Med Biol 2, 173189. (2001).

5. MacLean, M.R., Hervé, P., Eddahibi, S. \& Adnot, S. 5-hydroxytryptamine and the pulmonary circulation: receptors, transporters and relevance to pulmonary arterial hypertension. Br. J. Pharmacol. 131, 161-168. (2000).

6. Michelakis, E.D. \& Weir, E.K. Anorectic drugs and pulmonary hypertension from the bedside to the bench. Am. J. Med. Sci. 321, 292-299. (2001).

7. Egermayer, P., Town, G.I. \& Peacock, A.J. Role of serotonin in the pathogenesis of acute and chronic pulmonary hypertension. Thorax 54, 161-168. (1999).

8. Hervé, P. et al. Increased plasma serotonin in primary pulmonary hypertension. Am. J. Med. 99, 249-254 (1995).

9. Kéreveur, A. et al. High plasma serotonin levels in primary pulmonary hypertension : effect of long-term epoprostenol (Prostacyclin) therapy. Arterioscler. Thromb. Vasc. Biol. 20, 2233-2239 (2000). 
10. Ullmer, C., Schmuck, K., Kalkman, H.O. \& Lübbert, H. Expression of serotonin receptor mRNA in blood vessels. FEBS Lett. 370, 215-221 (1995).

11. Rich, S., Rubin, L., Walker, A.M., Schneeweiss, S. \& Abenhaim, L. Anorexigens and pulmonary hypertension in the United States: results from the surveillance of North American pulmonary hypertension. Chest 117, 870-874 (2000).

12. Abenhaim, L. et al. Appetite-suppressant drugs and the risk of primary pulmonary hypertension. International Primary Pulmonary Hypertension Study Group. N. Engl. J. Med. 335, 609-616. (1996).

13. Fitzgerald, L.W. et al. Possible role of valvular serotonin 5-HT2B receptors in the cardiopathy associated with fenfluramine. Mol. Pharmacol. 57, 75-81 (2000).

14. Launay, J.-M. et al. Ras involvement in signal transduction by the serotonin 5-HT2B receptor. J. Biol. Chem. 271, 3141-3147 (1996).

15. Nebigil, C.G., Launay, J.-M., Hickel, P., Tournois, C. \& Maroteaux, L. 5Hydroxytryptamine $2 \mathrm{~B}$ receptor regulates cell-cycle progression: Cross talk with tyrosine kinase pathways. Proc. Natl. Acad. Sci. USA 97, 2591-2596 (2000).

16. Ullmer, C., Boddeke, H.G.W.M., Schmuck, K. \& Lübbert, H. 5-HT2B receptormediated calcium release from ryanodine-sensitive intracellular stores in human pulmonary artery endothelial cells. Br. J. Pharmacol. 117, 1081-1088 (1996).

17. Glusa, E. \& Pertz, H.H. Further evidence that 5-HT-induced relaxation of pig pulmonary artery is mediated by endothelial 5-HT2B receptors. Br. J. Pharmacol. 130, 692-698 (2000).

18. Nebigil, C.G. et al. Serotonin 2B receptor is required for heart development. Proc. Natl. Acad. Sci. USA 97, 9508-9513 (2000).

19. Nebigil, C.G. et al. Ablation of serotonin 5-HT2B receptors in mice leads to abnormal cardiac structure and function. Circulation 103, 2973-2979 (2001).

20. Bonhaus, D.W. et al. RS-127445: a selective, high affinity, orally bioavailable 5-HT2B receptor antagonist. Br. J. Pharmacol. 127, 1075-1082 (1999).

21. Belknap, J.K., Orton, E.C., Ensley, B., Tucker, A. \& Stenmark, K.R. Hypoxia increases bromodeoxyuridine labeling indices in bovine neonatal pulmonary arteries. Am. J. Respir. Cell. Mol. Biol. 16, 366-371 (1997).

22. Rabinovitch, M. EVE and beyond, retro and prospective insights. Am. J. Physiol. 277, L5-12. (1999).

23. Vu, T.H. \& Werb, Z. Matrix metalloproteinases: effectors of development and normal physiology. Genes Dev. 14, 2123-2133. (2000).

24. MacLean, M.R. Pulmonary hypertension, anorexigens and 5-HT: pharmacological synergism in action? Trends Pharmacol. Sci. 20, 490-495 (1999).

25. Eddahibi, S., Raffestin, B., Launay, J.M., Sitbon, M. \& Adnot, S. Effect of dexfenfluramine treatment in rats exposed to acute and chronic hypoxia. Am. J. Respir. Crit. Care Med. 157, 1111-1119 (1998).

26. Eddahibi, S. et al. Attenuated hypoxic pulmonary hypertension in mice lacking the 5hydroxytryptamine transporter gene. J. Clin. Invest. 105, 1555-1562 (2000).

27. Steudel, W. et al. Sustained pulmonary hypertension and right ventricular hypertrophy after chronic hypoxia in mice with congenital deficiency of nitric oxide synthase 3. $J$. Clin. Invest. 101, 2468-2477 (1998).

28. Hoshikawa, Y. et al. Prostacyclin receptor-dependent modulation of pulmonary vascular remodeling. Am. J. Respir. Crit. Care Med. 164, 314-318. (2001).

29. Keegan, A., Morecroft, I., Smillie, D., Hicks, M.N. \& MacLean, M.R. Contribution of the 5-HT1B receptor to hypoxia-induced pulmonary hypertension. Converging evidence 
using 5-HT1B-receptor knockout mice and the 5-HT1B/1D-receptor antagonist GR127935. Circ. Res. 89, 1231-1229 (2001).

30. Rabinovitch, M. Problems of pulmonary hypertension in children with congenital cardiac defects. Chest 93, 119S-126S. (1988).

31. Zhao, L., Long, L., Morrell, N.W. \& Wilkins, M.R. NPR-A-Deficient mice show increased susceptibility to hypoxia-induced pulmonary hypertension. Circulation 99, 605-607 (1999).

32. Buczko, W., De Gaetano, G. \& Garattini, S. Effect of fenfluramine on 5hydroxytryptamine uptake and release by rat blood platelets. Br. J. Pharmacol. 53, 563359 (1975).

33. Rothman, R.B. et al. Evidence for possible involvement of 5-HT2B receptors in the cardiac valvulopathy associated with fenfluramine and other serotonergic medications. Circulation 102, 2836-2841. (2000).

34. Humbert, M. et al. Pulmonary arterial hypertension and type-I glycogen-storage disease: the serotonin hypothesis. Eur. Respir. J. 20, 59-65 (2002).

35. Naeije, R., Maggiorini, M., Delcroix, M., Leeman, M. \& Melot, C. Effects of chronic dexfenfluramine treatment on pulmonary hemodynamics in dogs. Am. J. Respir. Crit. Care Med. 154, 1347-1350. (1996).

36. Eddahibi, S. et al. Dexfenfluramine-associated changes in 5-hydroxytryptamine transporter expression and development of hypoxic pulmonary hypertension in rats. $J$. Pharmacol. Exp. Ther. 297, 148-154. (2001).

37. Eddahibi, S. et al. Serotonin transporter overexpression is responsible for pulmonary artery smooth muscle hyperplasia in primary pulmonary hypertension. J. Clin. Invest. 108, 1141-1150. (2001).

38. Rabinovitch, M. Linking a serotonin transporter polymorphism to vascular smooth muscle proliferation in patients with primary pulmonary hypertension. J. Clin. Invest. 108, 1109-1111. (2001).

39. Fanburg, B.L. \& Lee, S.L. A new role for an old molecule: serotonin as a mitogen. Am. J. Physiol. 272, L795-806 (1997).

40. Lee, S.L., Wang, W.W., Finlay, G.A. \& Fanburg, B.L. Serotonin stimulates mitogenactivated protein kinase activity through the formation of superoxide anion. Am. J. Physiol. 277, L282-291 (1999).

41. Pitt, B.R. et al. Serotonin increases DNA synthesis in rat proximal and distal pulmonary vascular smooth muscle cells in culture. Am. J. Physiol. 266, L178-186 (1994).

42. Sanchez, C. \& Hyttel, J. Comparison of the effects of antidepressants and their metabolites on reuptake of biogenic amines and on receptor binding. Cell. Mol. Neurobiol. 19, 467-489 (1999).

43. Cowan, K.N. et al. Complete reversal of fatal pulmonary hypertension in rats by a serine elastase inhibitor. Nat. Med. 6, 698-702 (2000).

44. Morrell, N.W. et al. Altered growth responses of pulmonary artery smooth muscle cells from patients with primary pulmonary hypertension to transforming growth factorbeta(1) and bone morphogenetic proteins. Circulation 104, 790-795. (2001).

45. Cowan, K.N., Jones, P.L. \& Rabinovitch, M. Regression of hypertrophied rat pulmonary arteries in organ culture is associated with suppression of proteolytic activity, inhibition of tenascin-C, and smooth muscle cell apoptosis. Circ. Res. 84, 1223-1233. (1999). 


\section{Acknowledgments}

This work has been supported by funds from the Centre National de la Recherche Scientifique, the Institut National de la Santé et de la Recherche Médicale, the Hôpital Universitaire de Strasbourg, the Université Louis Pasteur, and by grants from the Fondation de France and from the Association pour la Recherche contre le Cancer. We thank P. Hickel for excellent technical assistance, J. Odillard for animal care, Dr. V. Mutel, Pr. J.-L. Laplanche, Pr. M. Mark, for critical reading of the manuscript and for helpful discussions, Drs. M. Pando and S. Brooks for english corrections, Drs. V. Mutel and D. Mc Namara for the gift of RS-127445 and Drs. F. Mentré and F. Godmard for statistical expertise.

Correspondence should be addressed to L.M. (e-mail: lucm@igbmc.u-strasbg.fr). 


\section{Fig. 1 \\ a}

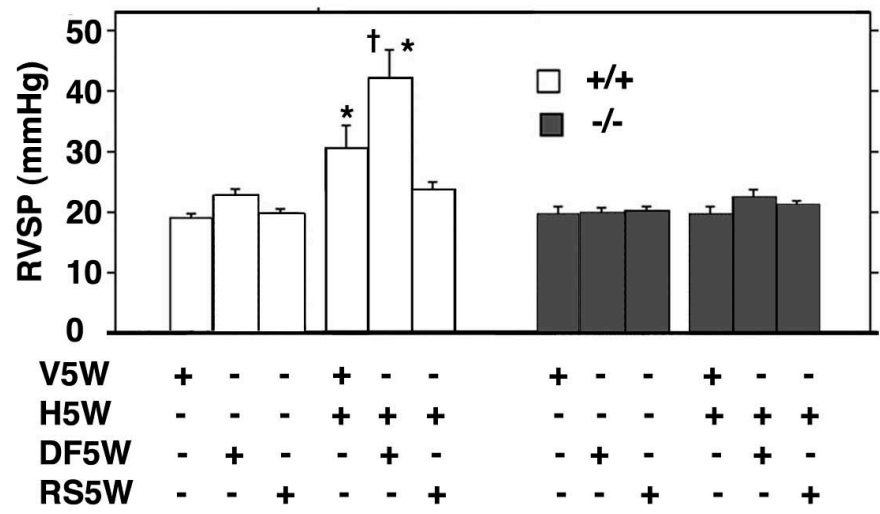

b

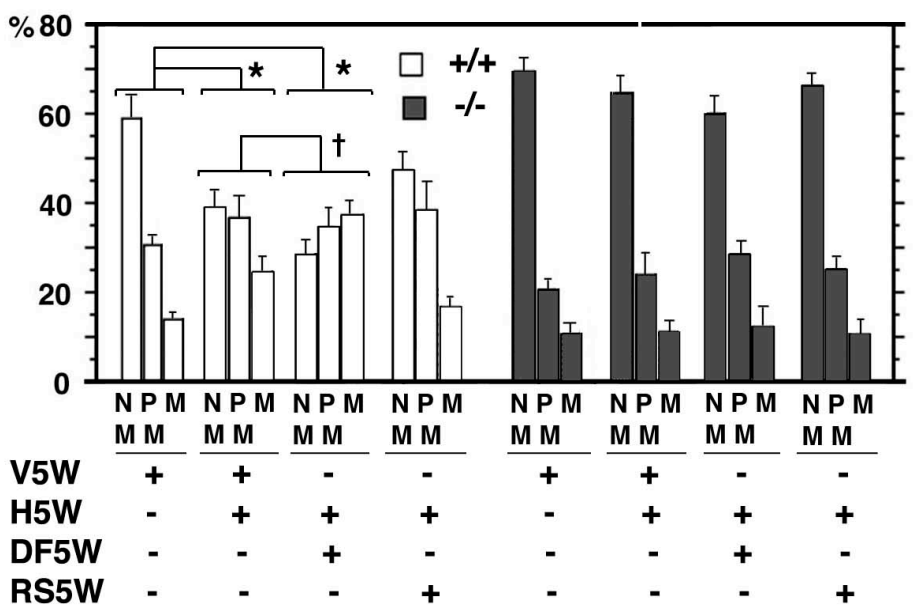

Figure 1 Requirement of 5- $\mathrm{HT}_{2 \mathrm{~B}} \mathrm{R}$ for hypoxia-induced RVSP and vascular muscularization. a In ${ }^{+/+}$mice exposed to hypoxia for 5 weeks (H5W), RVSP is significantly higher $(30.6 \pm 3.8 \mathrm{~mm} \mathrm{Hg}, \mathrm{n}=10)$ than in vehicle-treated normoxic ${ }^{+/}$mice $(\mathrm{V} 5 \mathrm{~W}, 18.5 \pm 0.4 \mathrm{~mm} \mathrm{Hg} \mathrm{n}=28)$. Simultaneous exposure of ${ }^{+/+}$mice to hypoxia in the presence of the specific $5-\mathrm{HT}_{2 \mathrm{~B}} \mathrm{R}$ antagonist $\mathrm{RS}$ (RS5W) prevents the increase in RVSP $(23.6 \pm 1.5 \mathrm{~mm} \mathrm{Hg}, \mathrm{n}=10)$ whereas the presence of DF (DF5W) further increases significantly the RVSP $(42.3 \pm 4.7 \mathrm{~mm} \mathrm{Hg}, \mathrm{n}=15)$. By contrast, none of the $5-\mathrm{HT}_{2 \mathrm{~B}}{ }^{-/-}$mice exposed to hypoxia for 5 weeks $(\mathrm{n}=7)$ exhibits any change in RVSP vs. vehicle-treated normoxic mutant mice $(n=9)$, neither in the presence of $\mathrm{RS}(\mathrm{n}=9)$ nor DF $(n=9)$. Chronic exposure of normoxia to these compounds alone is ineffective for both genotypes. Any statistical difference from normoxic untreated control values is indicated by an asterisk, and from chronic hypoxia values by a cross $(\mathrm{P}<0.05)$. b A significantly different degree of muscularization (muscular, M, partially muscular, PM, or non-muscular, NM) is observed in hypoxic pulmonary arteries compared with normoxic ${ }^{+/+}$mice $(\mathrm{P}<0.05)$. The degree of muscularization in the DF plus hypoxia mice is also significantly more severe than the plain hypoxia or the vehicle-treated mice $(\mathrm{P}<0.05)$. Alternately, the degree of pulmonary artery muscularization does not differ significantly from controls after RS treatment of hypoxic ${ }^{+/+}$mice or in hypoxia-treated $5-\mathrm{HT}_{2 \mathrm{~B}}{ }^{-/-}$mice with, or without, $\mathrm{RS}$ or DF. 


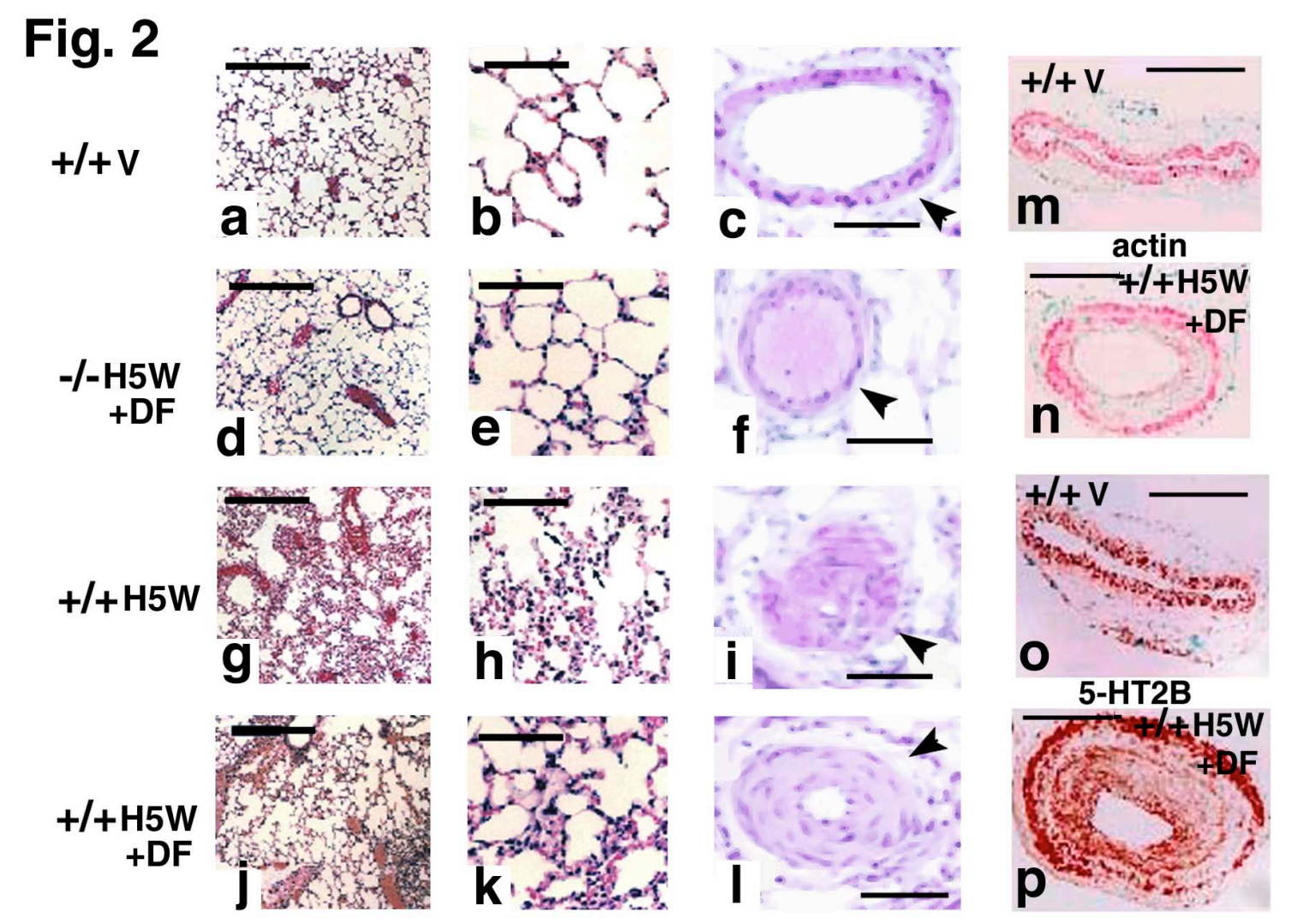

Figure 2 Requirement of 5- $\mathrm{HT}_{2 \mathrm{~B}} \mathrm{R}$ for hypoxia-induced lung remodeling. Sections of lung tissue of different genotype following different treatments, normoxic ${ }^{+/+}$mice $(a, b$, $\left.\mathrm{c}, \mathrm{m}, \mathrm{o},{ }^{+/+} \mathrm{V}\right)$, hypoxic ${ }^{+/+}$mice $\left(\mathrm{g}, \mathrm{h}, \mathrm{i},{ }^{+/+} \mathrm{H} 5 \mathrm{~W}\right)$, mice treated by hypoxia in the presence of $\mathrm{DF},{ }^{+/+}$mice $\left(\mathrm{j}, \mathrm{k}, \mathrm{l}, \mathrm{n}, \mathrm{p},{ }^{+/+} \mathrm{H} 5 \mathrm{~W}+\mathrm{DF}\right)$ or $5-\mathrm{HT}_{2 \mathrm{~B}}{ }^{-/-}$mice $\left(\mathrm{d}, \mathrm{e}, \mathrm{f},{ }^{-/-}\right.$ $\mathrm{H} 5 \mathrm{~W}+\mathrm{DF}$ ) are presented. Sections of lung tissue stained with haematoxilin at low magnification ( $a, d, g, j)$, and intermediate magnification $(b, e, h, k)$, illustrate the altered lung morphology and increased cell proliferation. At higher magnification, when compared with normoxic ${ }^{+/+}$mice $\left(\mathrm{c}, \mathrm{m}, \mathrm{o},{ }^{+/+} \mathrm{V}\right)$, the thickness of pulmonary vessels (arrowheads) media is clearly increased in hypoxic ${ }^{+/+}$mice $\left(\mathrm{i},{ }^{+/+} \mathrm{H} 5 \mathrm{~W}\right)$, and is further increased in the presence of DF $\left(1, n, p,{ }^{+/+} \mathrm{H} 5 \mathrm{~W}+\mathrm{DF}\right)$ whereas no modification of lung morphology was detected in normoxic $5-\mathrm{HT}_{2 \mathrm{~B}}{ }^{-/-}$mice, in $5-\mathrm{HT}_{2 \mathrm{~B}}{ }^{-/-}$mice after hypoxia with DF (f, $\left.{ }^{-/} \mathrm{H} 5 \mathrm{~W}+\mathrm{DF}\right)$ or without (not illustrated). The pulmonary vessels media is illustrated by van Giesen staining of elastin $(\mathrm{c}, \mathrm{f}, \mathrm{i}, \mathrm{l})$ or by staining with antibodies against smooth muscle alpha-actin ( $\mathrm{m}, \mathrm{n}$, actin) or against $5-\mathrm{HT}_{2 \mathrm{~B}} \mathrm{R}\left(\mathrm{o}, \mathrm{p}, 5-\mathrm{HT}_{2 \mathrm{~B}}\right)$. This staining reveals that the proliferating cell population are $5-\mathrm{HT}_{2 \mathrm{~B}} \mathrm{R}$ positive whereas only few $5-\mathrm{HT}_{2 \mathrm{~B}} \mathrm{R}$ positive cells could be observed in normoxic ${ }^{+/+}$mice. Bars $=500 \mu \mathrm{m},(\mathrm{a}$, d, g, j). Bars $=125 \mu \mathrm{m},(\mathrm{b}, \mathrm{e}, \mathrm{h}, \mathrm{k})$. Bars $=25 \mu \mathrm{m},(\mathrm{c}, \mathrm{f}, \mathrm{i}, \mathrm{l}, \mathrm{m}, \mathrm{n}, \mathrm{o}, \mathrm{p})$. 


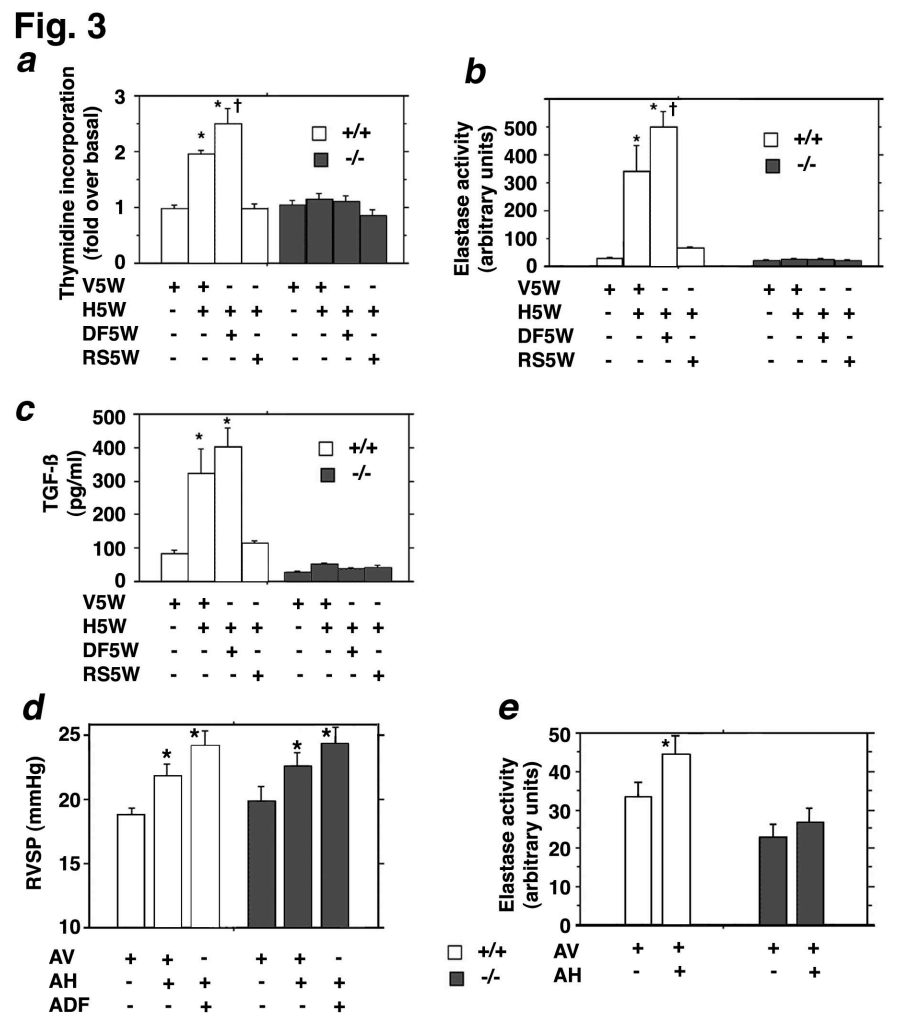

Figure 3 Requirement of $5-\mathrm{HT}_{2 \mathrm{~B}} \mathrm{Rs}$ for lung remodeling factors but not for acute vasoconstriction. a After exposure to hypoxia, ${ }^{+/+}$mice lung vasculature exhibits a significantly increased $(\mathrm{H} 5 \mathrm{~W}, 1.95 \pm 0.06$ times basal control, $\mathrm{n}=10)$ tritiated thymidine incorporation (per mg of tissue proteins), when compared normoxic with lung vessels (V5W, $0.99 \pm 0.05)$. The basal normoxic incorporation is $2112 \pm 355$ $\mathrm{cpm} / \mathrm{mg}$ of tissue proteins. This increase is significantly potentiated by DF (DF5W, 2.51 \pm 0.27 times basal, $\mathrm{n}=10)$ and completely prevented by either RS treatment $(\mathrm{RS} 5 \mathrm{~W})$ or by the elimination of $5-\mathrm{HT}_{2 \mathrm{~B}} \mathrm{R}$ in $5-\mathrm{HT}_{2 \mathrm{~B}}{ }^{-/-}$mice. $\mathrm{b}$ In ${ }^{+/+}$lung vessel explant supernatants, total elastolytic activity is significantly increased after chronic hypoxic exposure $(344 \pm 90 \mathrm{cpm} / \mathrm{mg}$ of tissue proteins, $\mathrm{n}=10 \mathrm{vs} .33 \pm 4$ for normoxia, $\mathrm{n}=19)$. A further significant increase is observed after chronic hypoxia in the presence of DF $(496 \pm 55 \mathrm{cpm} / \mathrm{mg}$ prot, $\mathrm{n}=15)$ while near normoxic values are obtained in the presence of RS $(67 \pm 4 \mathrm{cpm} / \mathrm{mg}$ prot, $\mathrm{n}=10)$. By contrast, hypoxia does not modify the elastolytic activity in supernatants of $5-\mathrm{HT}_{2 \mathrm{~B}}{ }^{-/-}$mice following either treatment. $\mathrm{c} \mathrm{In}{ }^{+/+}$ lung vessel explant supernatants, TGF- $\beta$ levels are significantly increased upon hypoxia $(322 \pm 72 \mathrm{pg} / \mathrm{ml} v s .83 \pm 10$ for normoxia, $\mathrm{n}=10)$. This increase is potentiated by DF $(401 \pm 56 \mathrm{pg} / \mathrm{ml})$ but blocked by RS $(114 \pm 8 \mathrm{pg} / \mathrm{ml})$. No significant TGF- $\beta$ level modification can be detected in supernatants of hypoxic lungs of $5-\mathrm{HT}_{2 \mathrm{~B}}{ }^{-/-}$mice after either treatment. $d$ Exposure to acute hypoxic challenges $(\mathrm{AH})$ triggers a significant increase in RVSP in both $5-\mathrm{HT}_{2 \mathrm{~B}} \mathrm{R}^{-/}(22.5 \pm 1.0 \mathrm{~mm} \mathrm{Hg}, \mathrm{n}=10)$ and ${ }^{+/+}(21.6 \pm 1.0$ $\mathrm{mm} \mathrm{Hg}, \mathrm{n}=10)$ mice, when compared with vehicle treated (AV) control mice $(18.9 \pm$ $1.0 \mathrm{~mm} \mathrm{Hg}, \mathrm{n}=10$ and $18.4 \pm 0.5 \mathrm{~mm} \mathrm{Hg}, \mathrm{n}=29$, respectively). DF administered $5 \mathrm{~min}$ before the hypoxic period (ADF) further increases these values independently of the mice genotype. e In ${ }^{+/+}$lungs, total elastolytic activity is significantly increased following acute hypoxic challenges $(43.4 \pm 6.1 \mathrm{cpm} / \mathrm{mg}$ of tissue proteins $v s .33 .0 \pm 3.6$ for normoxia) though it is not significantly modified in $5-\mathrm{HT}_{2 \mathrm{~B}} \mathrm{R}^{-/-}$mice $(26.7 \pm 4.2$ $\mathrm{cpm} / \mathrm{mg}$ of tissue proteins $v s .21 .9 \pm 4.5$ for normoxia). 
Fig. 4

a

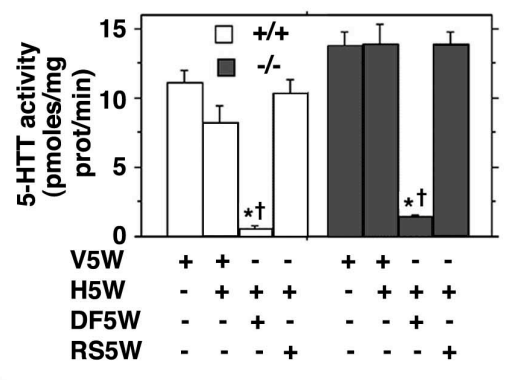

C

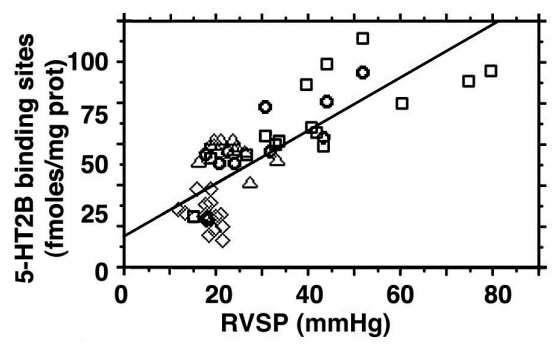

d

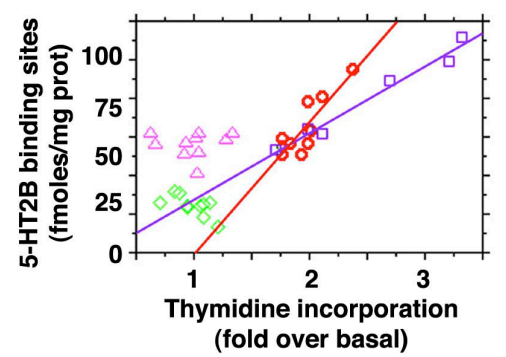

b

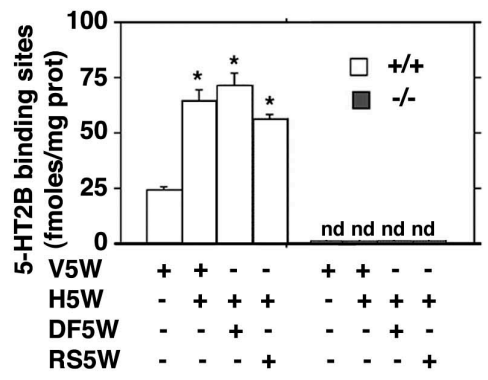

$+/+V 5 W$

$+/+\mathrm{H} 5 \mathrm{~W}$

$+/+$ H5W+DF5W

$+/+H 5 W+R S 5 W$

Figure 4 Hypoxia increases $5-\mathrm{HT}_{2 \mathrm{~B}} \mathrm{R}$ expression in lungs. a The uptake activity of lung vasculature from ${ }^{+/+}$hypoxic mice $(\mathrm{H} 5 \mathrm{~W})$ is non-significantly reduced by $23.4 \% \mathrm{vs}$. normoxic controls (V5W), corresponding to a $28.6 \%$ decrease of the maximal initial rate of uptake and no change in affinity for 5-HT. For the 5- $\mathrm{HT}_{2 \mathrm{~B}}{ }^{-/-}$mice, basal 5-HTT activity is slightly higher (by $24 \%$ ) than normoxic ${ }^{+/+}$values but is unaffected by hypoxia or RS (RS5W). DF treatment (DF5W) almost completely blocked the 5-HT uptake in the hypoxic ${ }^{+/+}$and $5-\mathrm{HT}_{2 \mathrm{~B}}{ }^{-/-}$mice. $\mathrm{b}$ Hypoxia increases significantly the number of $5-\mathrm{HT}_{2 \mathrm{~B}} \mathrm{R}$ specific binding sites $(64.7 \pm 4.7$ fmoles $/ \mathrm{mg}$ prot, $\mathrm{n}=10$ vs. $25.3 \pm$ 1.5 for normoxic lungs, $\mathrm{n}=19)$. This increase in $5-\mathrm{HT}_{2 \mathrm{~B}} \mathrm{R}$ binding sites is not significantly affected by either DF $(71.9 \pm 5.8$ fmoles $/ \mathrm{mg}$ prot, $\mathrm{n}=15)$ or RS $(56.0 \pm 2.0$ fmoles/mg prot, $\mathrm{n}=10)$. Indeed, $5-\mathrm{HT}_{2 \mathrm{~B}} \mathrm{R}$-specific sites were not detected in $5-\mathrm{HT}_{2 \mathrm{~B}}{ }^{-/-}$ mice (nd). c,d,e Correlation between parameters involved in PH development. A highly significant correlation $(\mathrm{P}<0.0001)$ is observed between all individual values of the number of 5-HT ${ }_{2 \mathrm{~B}} \mathrm{R}$ specific binding sites and the RVSP increase (c). Moreover, only when ${ }^{+/+}$mice are exposed to normoxia (+/+V5W, diamonds), hypoxia alone $(+/+\mathrm{H} 5 \mathrm{~W}$, circles) or with DF (+/+H5W+DF5W, squares) but not RS (+/+H5W+RS5W, triangles) (i.e. active $5-\mathrm{HT}_{2 \mathrm{~B}} \mathrm{R}$ ), the thymidine incorporation index correlates significantly with the number of $5-\mathrm{HT}_{2 \mathrm{~B}} \mathrm{R}$ binding sites $(\mathrm{r}=0.987$ for $+/+\mathrm{H} 5 \mathrm{~W}+\mathrm{DF} 5 \mathrm{~W}$ and 0.868 for $+/+$ H5W, both $\mathrm{P}<0.01$ ) (d) or the RVSP $(\mathrm{r}=0.952$ for $+/+\mathrm{H} 5 \mathrm{~W}+\mathrm{DF} 5 \mathrm{~W}, 0.939$ for $+/+\mathrm{H} 5 \mathrm{~W}$ and 0.827 for $+/+\mathrm{V} 5 \mathrm{~W}$, in each case $\mathrm{P}<0.01)(\mathrm{e})$. 


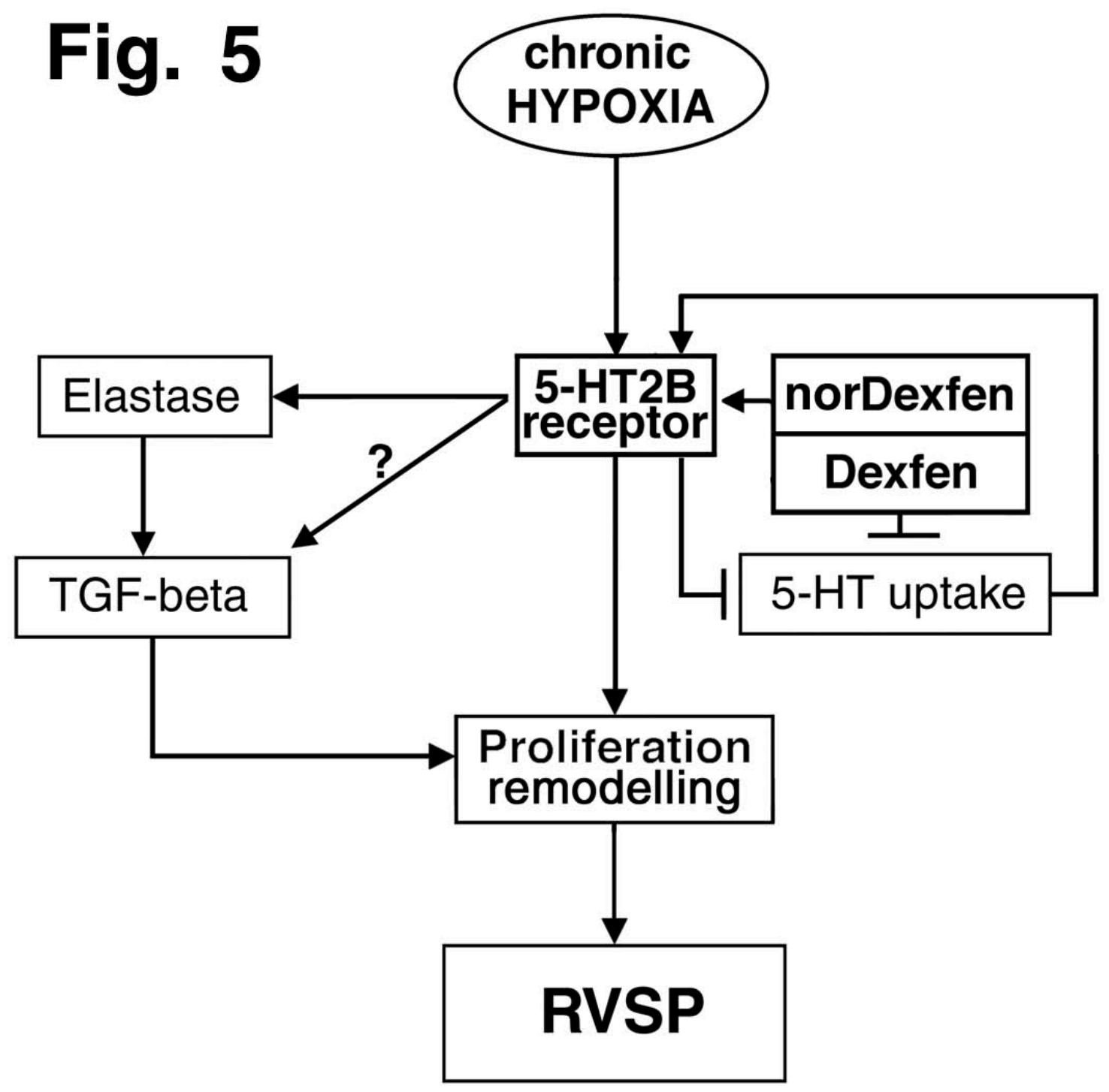

Figure 5 Model of 5- $\mathrm{HT}_{2 \mathrm{~B}} \mathrm{R}$-dependent hypoxia-induced RVSP in mice. Chronic hypoxia triggers a striking increase in $5-\mathrm{HT}_{2 \mathrm{~B}} \mathrm{R}$ expression. Chronic DF (Dexfen) potentiates hypoxia by affecting RVSP through activation of $5-\mathrm{HT}_{2 \mathrm{~B}} \mathrm{R}$ by norDF (norDexfen), with an amplification from 5-HTT blockage. Lung proliferation and remodeling also appear to be dependent on the $5-\mathrm{HT}_{2 \mathrm{~B}} \mathrm{R}$ signaling activity and involve extracellular elastase activation and increase of TGF- $\beta$ levels. 
Table I - Evaluation of RV/LV+S

\begin{tabular}{lllllllll} 
& $+/+\mathrm{V}$ & $+/+\mathrm{DF} 5 \mathrm{~W}$ & $+/+\mathrm{H} 5 \mathrm{~W}$ & $+/+\mathrm{H} 5 \mathrm{WDF}$ & $-/-\mathrm{V}$ & $-/-\mathrm{DF} 5 \mathrm{~W}$ & \multicolumn{2}{l}{$-/$-H5W $-/-\mathrm{H} 5 \mathrm{WDF}$} \\
$\mathrm{RV} / \mathrm{LV}+\mathrm{S}$ & 0.21 & 0.19 & 0.29 & 0.39 & 0.46 & 0.45 & 0.47 & 0.46 \\
$(\% \pm \mathrm{sem})$ & \pm 0.01 & \pm 0.03 & $\pm 0.03 *$ & $\pm 0.04 * \dagger$ & \pm 0.01 & \pm 0.04 & \pm 0.02 & \pm 0.02 \\
$\mathrm{n}$ & 10 & 10 & 14 & 15 & 9 & 10 & 7 & 8
\end{tabular}

Abbreviations: ${ }^{+/+}$mice exposed to hypoxia for 5 weeks $\left({ }^{+/+} \mathrm{H} 5 \mathrm{~W}\right)$, vehicle-treated normoxic ${ }^{+/+}$mice $\left({ }^{+/+} \mathrm{V}\right)$. ${ }^{+/+}$mice exposed to hypoxia in the presence of DF $\left({ }^{+/+} \mathrm{H} 5 \mathrm{WDF}\right), 5-\mathrm{HT}_{2 \mathrm{~B}}{ }^{-/-}$mice exposed to hypoxia for 5 weeks $\left({ }^{-/} \mathrm{H} 5 \mathrm{~W}\right)$, vehicle-treated normoxic $5-\mathrm{HT}_{2 \mathrm{~B}}{ }^{-/-}$mice $\left({ }^{-/} \mathrm{V}\right)$, in the presence of DF $\left({ }^{-/} \mathrm{H} 5 \mathrm{WDF}\right)$, and mice exposed chronically to these compounds alone $\left({ }^{+/+} \mathrm{DF} 5 \mathrm{~W},{ }^{-/} \mathrm{DF} 5 \mathrm{~W}\right)$. Any statistical difference from normoxic untreated control values is indicated by an asterisk and from chronic hypoxia values by a cross $(\mathrm{P}<0.05$, Kruskal-Wallis test $)$.

Table Supplementary Data - DF and norDF plasma levels (in $\mathrm{nM} \pm \mathrm{SEM}$ ).

$\begin{array}{lllllllll} & +/+\mathrm{V} & +/+\mathrm{DF} 5 \mathrm{~W} & +/+\mathrm{H} 5 \mathrm{WDF} & +/+\mathrm{AHDF} & -/-\mathrm{V} & -/-5 \mathrm{WDF} & -/-\mathrm{H} 5 \mathrm{WDF} & -/-\mathrm{AHDF} \\ \mathrm{DF} & 0 & 6,4 \pm 0,8 & 7,2 \pm 0,5 & 425 \pm 65 & 0 & 13,5 \pm 16 & 8,9 \pm 1,1 & 391 \pm 43 \\ \text { norDF } & 0 & 526 \pm 74 & 570 \pm 56 & 2,7 \pm 0,2 & 0 & 481 \pm 26 & 565 \pm 76 & 4,2 \pm 0,7 \\ \mathrm{n} & 10 & 10 & 6 & 9 & 9 & 10 & 8 & 10\end{array}$

DF and norDF plasma levels were measured by HPLC (Midha, K.K. et al., 1983). Abbreviations: ${ }^{+/+}$mice exposed to hypoxia for 5 weeks $\left({ }^{+/+} \mathrm{H} 5 \mathrm{~W}\right)$, vehicle-treated normoxic ${ }^{+/+}$mice $\left(\mathrm{C}^{+/+} \mathrm{V}\right) .{ }^{+/+}$mice exposed to hypoxia in the presence of $\mathrm{DF}$ $\left({ }^{+/+} \mathrm{H} 5 \mathrm{WDF}\right), 5-\mathrm{HT}_{2 \mathrm{~B}}{ }^{-/-}$mice exposed to hypoxia for 5 weeks $\left({ }^{-/} \mathrm{H} 5 \mathrm{~W}\right)$, vehicle-treated normoxic 5-HT $2{ }^{-/-}$mice $\left({ }^{-/} \mathrm{V}\right)$, in the presence of DF $\left({ }^{-/} \mathrm{H} 5 \mathrm{WDF}\right)$, and mice exposed chronically to these compounds alone $\left({ }^{+/+} \mathrm{DF} 5 \mathrm{~W},{ }^{-/} \mathrm{DF} 5 \mathrm{~W}\right)$, mice exposed to five successive acute hypoxic challenges in 5- $\mathrm{HT}_{2 \mathrm{~B}} \mathrm{R}^{-/-}\left({ }^{-/-} \mathrm{AH}\right)$ or ${ }^{+/+}\left({ }^{+/+} \mathrm{AH}\right)$ mice and mice exposed to five successive acute hypoxic challenges in the presence of DF administered 5 min before the hypoxic period $\left({ }^{+/+}\right.$AHDF, ${ }^{-/-}$AHDF $)$.

Reference:

Midha, K.K. et al. The identification of two new urinary metabolites of fenfluramine in man. Xenobiotica 13, 31-38. (1983). 